\title{
The Santa Paula Photovoice Project: CRP 410 and 411 Work in Fall and Winter Quarter, 2011-2012
}

\author{
Kelly Main \\ PhD; associate professor, CRP Department.
}

\begin{abstract}
Instructor Kelly Main writes about one of the community outreach techniques utilized in her CRP 410/41 1 class for the update of the City of Santa Paula's Downtown Improvement Plan. The Photovoice is designed to empower participants to tell their stories through photographs and narratives which are then analysed and incorporated in the proposed plan.
\end{abstract}

\section{In} n September 2011, the City of Santa Paula retained students in Cal Poly's City and Regional Planning program to update the City's Downtown Improvement Plan. Santa Paula, a city of approximately 30,000, is located in Central California twelve miles from the Pacific Ocean. Nestled in the Santa Clara Valley, Santa Paula has a historic downtown and is frequently used in Hollywood films to represent quintessential "small-town USA." Once known for its abundance of oil, Santa Paula's surrounding agriculture now makes this area "the citrus capital of the world."

Seniors in the Department's community planning laboratory undertook the update of the Downtown Improvement Plan for Fall and Winter Quarter. The project was supervised by Assistant Professor Kelly Main and visiting Lecturer Keith Woodcock,. Santa Paula's Planning Director, Janna Minsk, a graduate of Cal Poly's Masters Program in City and Regional Planning, provided support and guidance regarding the City's issues and concerns. One of the goals for the project was maximizing public participation; Cal Poly students completed more than 150 surveys in both English and Spanish, conducted mapping exercises at a local grocery store and soccer fields, and held a focus group meeting with community members, In order to find out what high schools students in Santa Paula might want in the downtown, Dr. Main and Mr. Woodcock decided to use photovoice-a technique designed to empower participants to tell their stories through photos and narratives-with students at Santa Paula High School.

The use of photovoice as a tool for community involvement has been growing since it was first developed by C. C. Wang at the University of Michigan and M. A. Burris, a program director for public health at the Ford Foundation. In 1992, Wang and Burris completed a "Photo Novella" project with rural women in the Yunnan province in China to enable the women to affect government actions and polices affecting them (Wang \& Burris, 1997). Utilized most frequently in the field of public health, photovoice projects have been completed on a diverse variety of issues-such as women's health, maternal and child health, individuals living with HIV, the influence of immigration on Latino adolescents -and as a tool for youth advocacy on health issues (Kramer et al, 2010; Healthy Living, 2009). With the growing interest in the relationship between public health and the built environment, photovoice has come to the attention of city planners, such as Woodcock, who used photos and narratives generated by children in the Central Valley for a comprehensive plan update (Hodgson, 2009).

The Santa Paula Photovoice Project was sponsored by STRIDE, (Science through Translational Research in Diet and Exercise), an interdisciplinary research center at Cal Poly that promotes healthier living. Dr. Ann McDermott, STRIDE's Director, strongly supported the idea of exploring high school students' perceptions of the relationship between public health and the built environment. Nicola Lamb, English Department Chair at Santa Paula High School, took on the project with forty-two students in two senior-level English classes.

Under Ms. Lamb's supervision, students were asked to use photos and narratives to address four questions about Santa Paula: What do you like about your city? What would you like to change? How does the city (built environment) support health? How could the city be healthier? The high school students received disposable cameras and instructions about how to tell a story using photos and narratives. For almost three months, with guidance from Lamb and input from Woodcock and Main, the students explored their city.

Once Ms. Lamb's students completed the project, they told their stories to CRP's community planning laboratory. CRP students were responsible for identifying issues raised by the students and addressing them in the Downtown Improvement Plan. It was interesting to learn that high school students echoed many of the same concerns heard from other Santa Paulans who participated in the project-the importance of preserving the historic and small-town feeling of Santa Paula, the need for more variety in the businesses on Main Street, and the improve- 
ments needed to streets and parks. High school students also raised their own unique issues, such as concerns about gang graffiti, how much they loved the new bike path in town, how they wanted more activities to be healthy, how many of them had two-working parents and needed something safe and constructive to do in the afternoon, how proud they were of their community's farmworker heritage and the new monument in town to farmworkers. The photos and narratives allowed students to tell very specific stories about the places in Santa Paula that were special to them, needed improvement, and affected their activity level. The following are just a few of the nearly thirty stories and 120 photographs the students created:

"This town should reflect its own true beauty with its people, attractive architecture, and gorgeous landscape that are depicted through our murals around Santa Paula" - Yesenia and Maria

"There are some things that we enjoy about Santa Paula. We enjoy the city's antique and historical look. We have beautiful murals throughout the town, and an amazing view overlooking the valley and the ocean. We have a nice depot and a clock tower as our city landmarks. And with our new bike trail, we like that it has an emergency button every so many miles, to keep our community safe." -Angelica

"The lovely and historic town of Santa Paula consists of beautiful murals, significant monuments, and astounding views... Our city portrays remarkable views unlike any other city's in which it emphasizes the beach, our citrus fields, and our mesmerizing mountain views." - Anakaren and Deisi

"Public parks are enjoyed by people of all ages, from school children who want to play on the playground, to young adults playing basketball, and even to older people just wanting to get some fresh air... Even so, one is left to wonder why so few families visit Santa Paula's Park?" - Adalit and Stephanie

"Keeping the parks in Santa Paula sanitary and safe must be amongst the higher priorities for city officials. Improvements have been made, but there is much more work to do. Parks located around the main attractions of Santa Paula have been kept in good shape; however, parks that are not frequently viewed by anyone else than the people who happen to live in the neighborhood have been neglected, and are in need of drastic changes." - Brittany

"Recently, Santa Paula High School built a new track for the city. Before the new track was built, it was always open to the public. Technically, the tennis courts are school property too, but it is always open to public use, unlike the track. It makes our high school look hypocritical because our parents, thus the whole city, help pay for the new track." -Karla

"Historic downtown Main Street has great potential, but it's going to need a little help from the community, whether it's opening a business or just supporting the businesses by shopping and spending money there. Santa Paula lacks retail stores, entertainment options, and variety when it comes to dining. Lately our town has

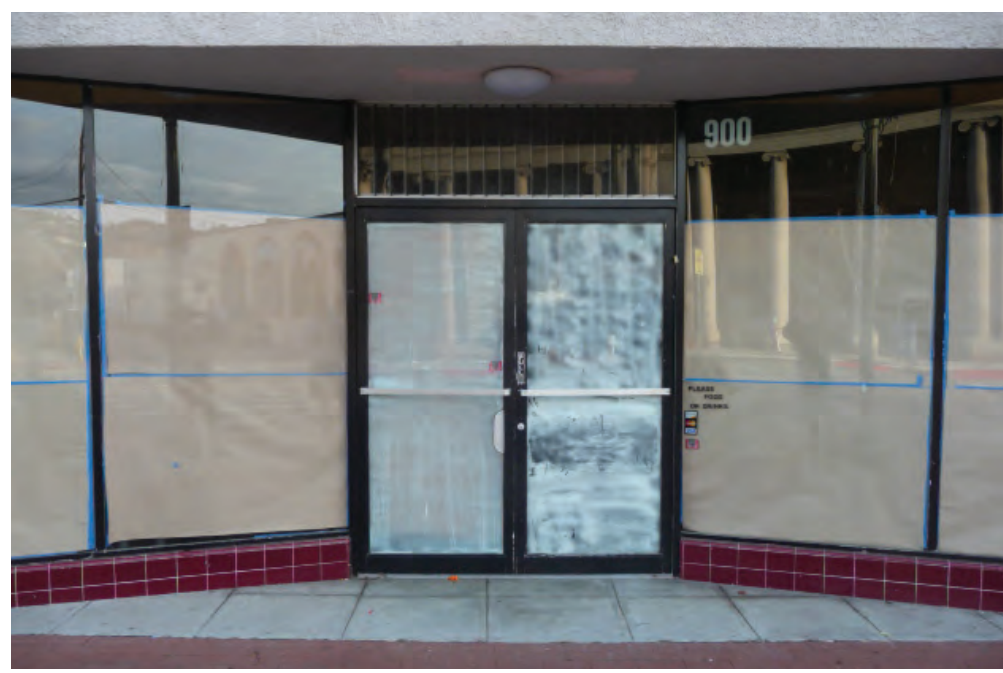

Figure 1: The street of emptiness.

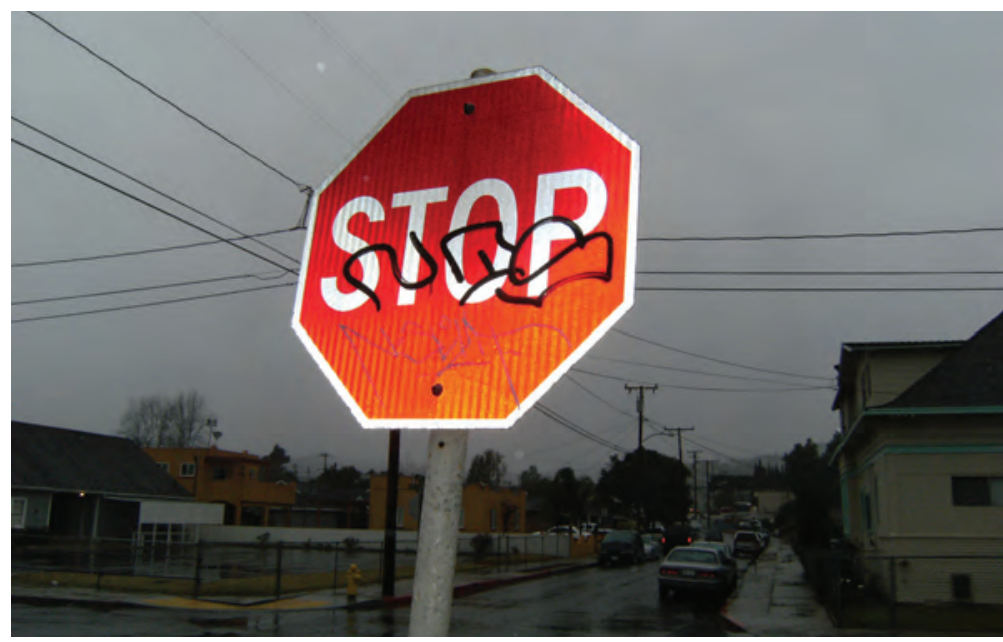

Figure 2: Two points of view (Elmer).

Figure 3: Beautiful murals, ugly truth (Yesenia and Maria)

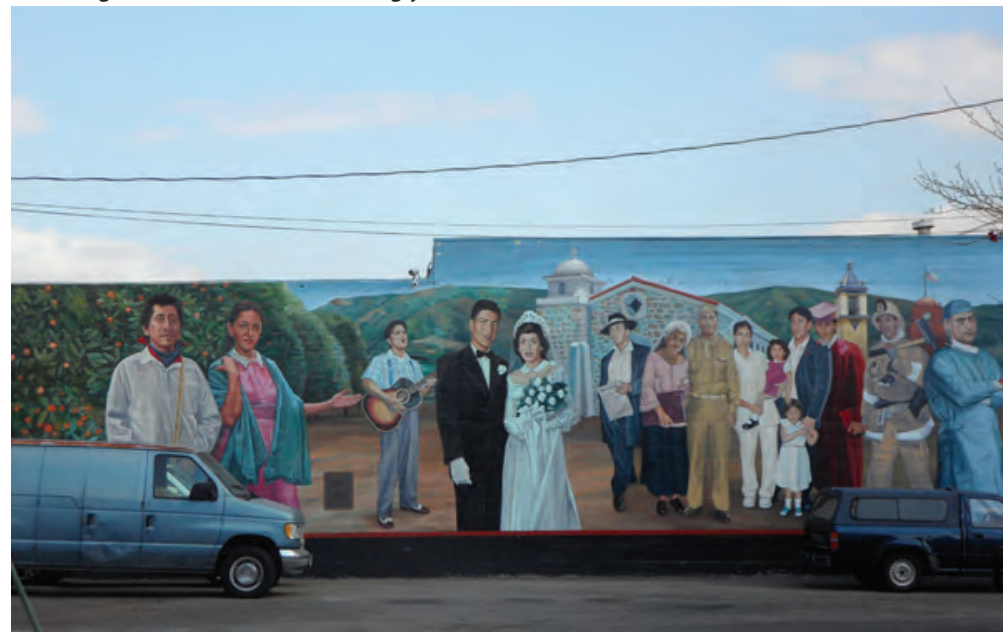


Following the presentation by high school students, community planning laboratory students incorporated policies, programs, and ideas into the updated Downtown Improvement Plan to address the issues and concerns raised by Santa Paula High School students, including historic preservation, park improvements, street improvements, an entertainment district, and a children's public art program. In addition, a recommendation for the creation of a Youth Commission was included in the plan, to lay the foundation for continued participation by Santa Paula's students. The photos and narratives of the students have been included in the Downtown Improvement Plan and will be exhibited in both San Luis Obispo and in Santa Paula.

The Santa Paula Photovoice Project accomplished the community planning laboratory's goals: to find out what students at Santa Paula High School liked about their town, where they saw need for change and improvement, and what might help them lead active and healthier lives. The project's most important outcome, however, may not have been the specific issues that were raised, as informative and relevant to the Downtown Plan as they were. In the end, Photovoice may have been most valuable for the effect it had on both CRP and Santa Paula High School students. In the tradition of photovoice, the participants should speak for themselves:

"What I got out of this was we should listen to kids more often." -Tyler English, Community Planning Lab Student, BSCRP.

"I guess I never really realized how important community outreach was. And after this class, after photovoice-it's highly important." -Anu Dhaliwal, Community Planning Lab Student, BSCRP

"Our town just usually doesn't get the recognition it should and that's what this project [Photovoice] did for us." -Gabriel, Santa Paula High School.

"I'd recommend this project [photovoice] to other schools 'cause they can go out and see their city the way it is... what's wrong and what's good about the city, and then learn from it and show others the city, and the city can be improved." -Rosalino, Santa Paula High School

"I think it made them [the high school students] better citizens...It kind of gave them confidence in themselves that they are, in fact, citizens of this town and they have a voice." -Nicola Lamb, English Department Chair, Santa Paula High School.

Author's Note: More information on The Santa Paula Photovoice Project and the Downtown Improvement Plan can be found at www.planning.calpoly.edu. A video on the project is available at http://youtu.be/hWnKI6bakFM

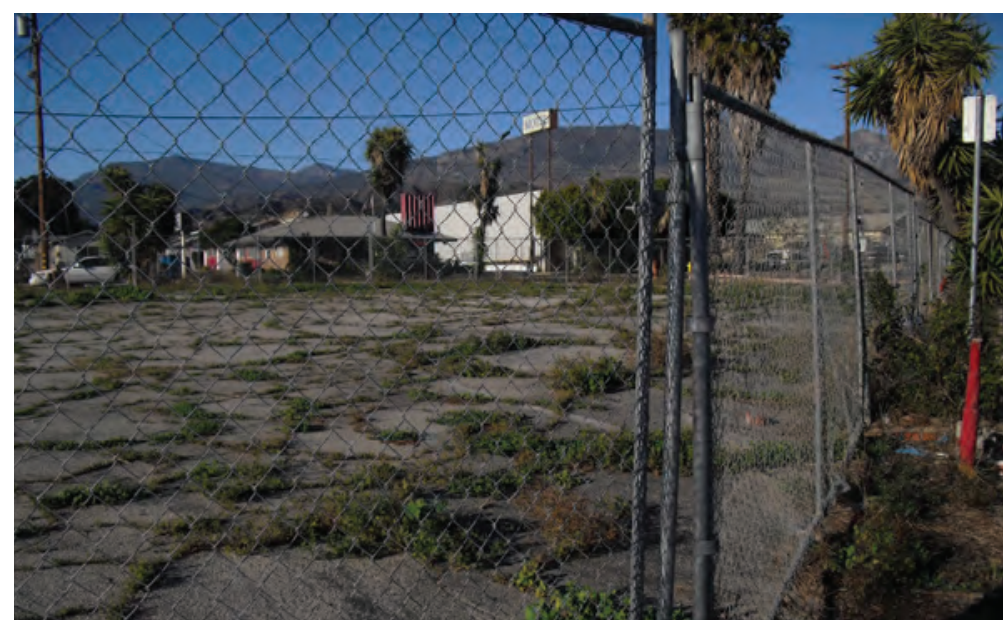

Figure 7: Butterfly farm (Sandra and Camille).

Figure 8: Park.

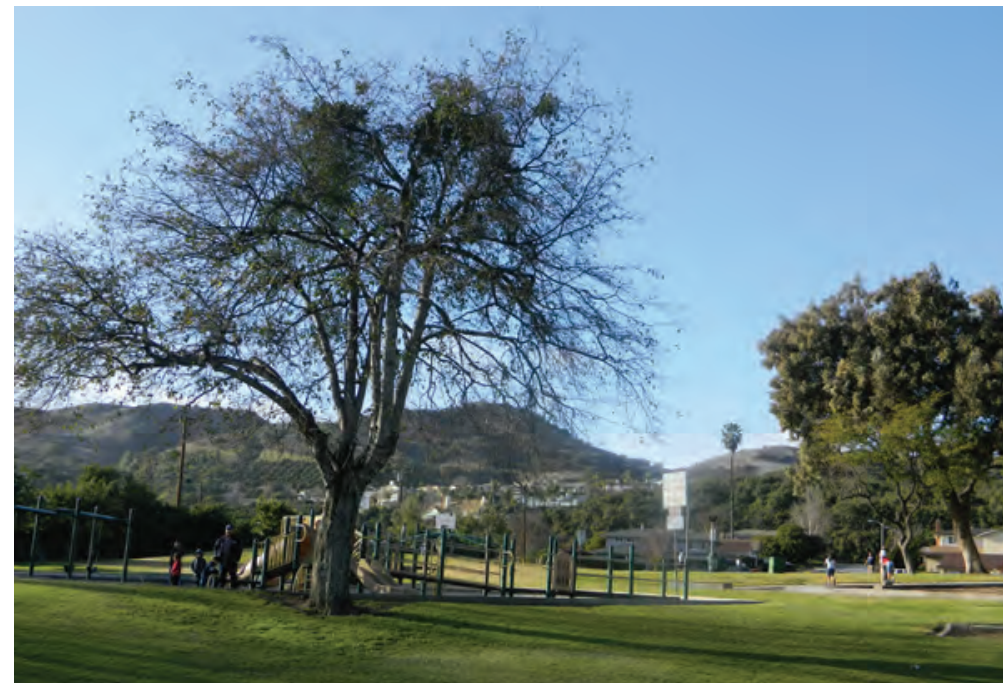

\section{References}

Wang, C. C., \& Burris, M. A. 1997. Photovoice: Concept, methodology, and use for participatory needs assessment. Health Education \& Behavior 24, 369-387.

Kramer, L., Schwartz, P., Cheadle, A., Borton, J.E., Wright, M. Chase, C., Lindley, C. 2010. Promoting Policy and Environmental Change: Using Photovoice in the Kaiser Permanente Community Health Initiative. Health Promotion Practice 11, 332-339.

3 lic's Health. 2009. Photovoice as a Tool for Youth Policy Advocacy. Public Health Institute: Oakland, California.

Hodgson, K. 2009. Where Food Planning and Health Intersect. Planning Magazine 75 (8), August/September, 9-13. 